\title{
Inspection of Endothelial Nitric Oxide Synthase Gene Polymorphism in Patients With Henoch Schönlein Purpura
}

\author{
Makbule Nihan SOMUNCU' ${ }^{1}$, Mahmut Selman YILDIRIM¹, Ayşegül ZAMANİ¹, Harun PERU² \\ ${ }^{1}$ Department of Medical Genetics, Necmettin Erbakan University, Meram Medical Faculty, Konya, Turkey \\ ${ }^{2}$ Department of Pediatric Nephrology, Selçuk University, Selçuklu Faculty of Medicine, Konya, Turkey
}

\begin{abstract}
Objectives: This study aims to investigate the effect of Glu298Asp polymorphism, which is observed at endothelial nitric oxide synthase isoform particularly, having a significant impact on endothelial functions of nitric oxide synthase gene and on vascular system in patients with Henoch Schönlein purpura (HSP).

Patients and methods: Ninety-five patients who were diagnosed with HSP and 93 healthy controls without any previous vascular disease, hypertension and other cardiovascular diseases were included in this study. The patient group was compared with the controls for Glu298Asp genotype and allele frequencies. The patients were classified according to the clinical complications and were compared with controls and also each other for allele and genotype frequencies. Real-time polymerase chain reaction and LightCycler ${ }^{\circledR} 2.0$ system were used.

Results: There was no statistically significant difference in the genotype frequencies between the HSP patients and healthy controls. No significant differences in Glu298Asp gene polymorphism among the patient groups were observed. However, polymorphism had an significant effect on patients with all involvements statistically $\left(\mathrm{P}_{\mathrm{TT}}=0.001, \mathrm{P}_{\mathrm{GG}}=0.000\right)$.

Conclusion: We conclude that Glu298Asp polymorphism has no effect on the development of HSP vasculitis; however, it may have an impact on the clinical progress of the existing disease.

Keywords: Endothelial nitric oxide synthase gene; Glu298Asp polymorphism; Henoch Schönlein purpura; real time polymerase chain reaction.
\end{abstract}

Henoch Schönlein purpura (HSP) is the most common leukocytoclastic vasculitis of childhood. This type of vasculitis is characterized by tissue deposition of immunoglobulin A containing immune complexes. As a result of this accumulation, particluarly intense neutrophil infiltration, small vessels are damaged in endothelial tissue., ${ }^{1,2}$

Major clinical features of HSP are palpable purpura, joint, gastrointestinal tract, renal involvement, all of which have great importance for determining the prognosis of $\mathrm{HSP}^{3}$ The etiology of this vascular syndrome, known for 200 years, has not yet been clarified. There are many reasons associated with HSP including age, sex, specific pathogens, and environmental and genetic factors. ${ }^{4}$ The disease can occur from the age of six months to adulthood. It is generally benign and self-limiting in children, but more severe in adults and boys are often more affected than girls. ${ }^{5}$ Genetic variants have previously been reported to influence either disease susceptibility or gastrointestinal ${ }^{6}$ and renal complications. ${ }^{7-9}$ In some molecular studies, it is indicated that genes can have many effects on the HSP phenotype, and heritage can play a role in the heterogeneity of vasculitis. ${ }^{10,11}$

Nitric oxide (NO) was clearly identified as a vasodilator molecule synthesized from the amino acid L-arginine in mammalian vascular endothelial cells. Because of its vasodilator activity, NO leads to increased cyclic guanosine monophosphate (cGMP) in blood vessel wall activating guanylatcyclase and leading to relaxation of smooth muscles in the endothelium. ${ }^{12}$ In addition, endothelial nitric oxide synthase (eNOS) protects the endothelium by inhibiting expression

Received: April 04, 2013 Accepted: September 05, 2013

Correspondence: Makbule Nihan Somuncu, M.D. Necmettin Erbakan Üniversitesi Meram Tıp Fakültesi, Tıbbi Genetik Anabilim Dalı, 42080 Akyokuş, Meram, Konya, Turkey. Tel: +90 332 - 2236680 e-mail: mnsomuncu@gmail.com

o2014 Turkish League Against Rheumatism. All rights reserved. 
of endothelial adhesion molecules on the surface. Preventing the proliferation of vascular smooth muscle plays an important role in the control of vascular tone. ${ }^{13}$ Otherwise, both aggregation and adhesion of platelets to NO via cGMP may inhibit the formation of thrombus. Other roles of NO include a significant impact on renal blood flow, autoregulation, and the regulation of glomerular filtration. ${ }^{14-16}$ It is an most important endogenous molecule that organizes endothelium functions as inhibiting platelet aggregation and vascular smooth muscle cell proliferation. ${ }^{17}$ It was suggested that inflammatory effect of $\mathrm{NO}$ in the vascular damage is caused by immune complexes. ${ }^{18}$

G894T, the most common variant of eNOS polymorphism, has been reported to have an effect on vascular endothelium. In this single nucleotide polymorphism, aspartat (Asp) aminoacid is synthased instead of glutamate (Glu) at 298, due to the transformed $\mathrm{G}$ into $\mathrm{T}$ at the nucleotide position 894 in exon 7. This replacement leads to reduced enzymatic activitiy, proteolytic cleavage and a decrease in nitric oxide bioavailability. As a result, impaired eNOS bioactivity was found to be associated with endothelial dysfunction, faster renal disease progression and pathological changes in blood vessel. ${ }^{19}$

In this study, the effect of the most common variant Glu298Asp polimorphism at eNOS isoform, which has a significant impact on endothelial functions of the NOS gene and known with its effects on the vascular system, on individuals with HSP is investigated.

\section{PATIENTS AND METHODS}

Ninety-five patients (34 females, 61 males; mean age $7.1 \pm 1.1$ years; range 2 to 17 years) were recruited from the Pediatric Nephrology Department of Necmettin Erbakan University Meram Medical Faculty. They were all diagnosed as HSP according to the 1990 American College of Rheumatology classification criteria for HSP vasculitis. ${ }^{20}$ The control group ( $\left.\mathrm{n}=93\right)$, consisted of 35 females and 58 males (mean age 28.2 \pm 0.8 years; range 18 to 35 years) determined to be healthy by physical examination. Informed consent was obtained from all patients and the study protocol was approved by the Meram
Medical Faculty Ethics Committee (Approval number: 2008/236)

For e-NOS G894T (rs 1799983; Glu298Asp) polymorphism genotyping, venous blood samples were collected in ethylenediaminetetraacetic acid (EDTA) containing tubes. Samples were stored at $-20{ }^{\circ} \mathrm{C}$ until the assay genomic DNA was isolated and purified using the high pure PCR template preperation kit according to the manufacturer's instructions (QIAamp Blood Kit, Qiagen, $\mathrm{GmbH}$, Hilden, Germany).

Light Cycler (LC) amplification was performed in a final volume of $20 \mu \mathrm{L}$ in the LC-glass capillaries. The reaction mixture consisted of $7.4 \mu \mathrm{L}$ of $\mathrm{H}_{2} \mathrm{O}, 1.6 \mu \mathrm{L}$ of $\mathrm{MgCL} 2(25 \mathrm{mM})$, $4.0 \mu \mathrm{L}$ reagent mix containing primers (NOS forward 5'-CACTCCCCACAGCTCTGCAT-3' and NOSreverse 5'-CAATCCCTTTGGTGCTCA CG-3'), $2.0 \mu \mathrm{L}$ master mix containing probes. It was mixed gently, spinned down and $15 \mu \mathrm{L}$ each of the reaction mixture was finally transfered to a light cycler capillary, $5 \mu \mathrm{L}$ sample or control DNA was added to each capillary for a final reaction volume of $20 \mu \mathrm{L}$. The cycling conditions for e-NOS G894T polymorphism detection include an initial denaturation at $95{ }^{\circ} \mathrm{C}$ for 10 minutes, followed by 45 cycles with a fast denaturation at $95{ }^{\circ} \mathrm{C}$ with an incubation time of 5 seconds (s), annealing at $60{ }^{\circ} \mathrm{C}$ for $10 \mathrm{~s}$ and extension at $72{ }^{\circ} \mathrm{C}$ for $15 \mathrm{~s}$ with a ramping time of $20{ }^{\circ} \mathrm{C} / \mathrm{s}$.

After amplification, melting curves were generated following 1 cycles of the reaction at $95^{\circ} \mathrm{C}$ for $20 \mathrm{~s}$, at $40{ }^{\circ} \mathrm{C}$ for $20 \mathrm{~s}$ and at $85^{\circ} \mathrm{C}$ for 0 s. Finally, 1 cycle for cooling at $40{ }^{\circ} \mathrm{C}$ for $0 \mathrm{~s}$. The result is a single melting peak at a temperature of $52.0^{\circ} \mathrm{C}$ in channel 640 . Heterozygous patients show two melting peaks $\left(52.5{ }^{\circ} \mathrm{C}\right.$ and $\left.59.0{ }^{\circ} \mathrm{C}\right)$ (Figure 1).

\section{Statistical analysis}

Statistical analyses were carried out by using the SPSS version 15.0 for Windows software program (SPSS Inc., Chicago, IL, USA). The eNOS genotype and allele frequencies of HSP and the control group were compared using the Fisher exact, two-proportion $\mathrm{Z}$ and Chi-square tests. $\mathrm{P}<0.05$ was considered significant for all statistical analyses. Logistic regression analyses were performed to estimate odd ratios (OR) with 95\% confidence intervals (CI). 

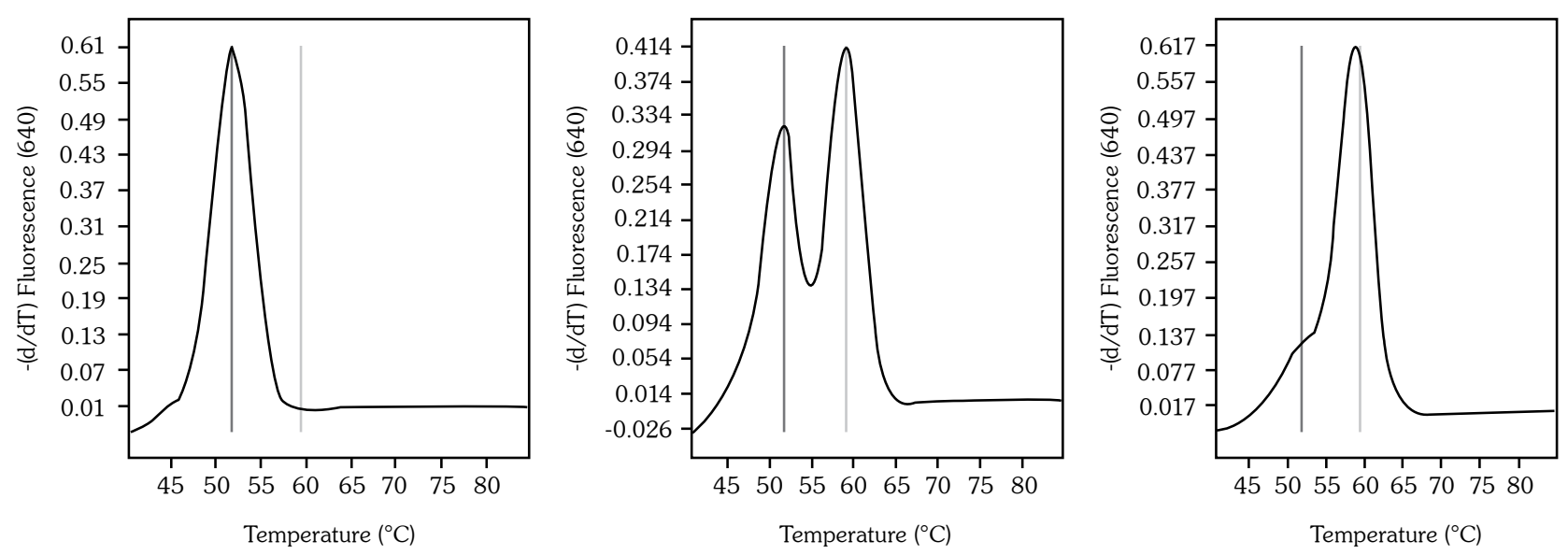

Figure 1. Melting peaks of eNOS gene (G894T) on real time polymerase chain reaction. (a) Wild type phenotype (GG). (b) Heteyrozygot phenotype (GT). (c) Mutant phenotype (TT)

\section{RESULTS}

The male sex was 1.79 times higher than the female sex in the HSP group. This difference was considered statistically significant $(p<0.05)$. The mean sex ratio in this study was compatible with the literature data.

In this study, we investigated the association of eNOS G894T polymorphism with HSP. We analyzed a single nucleotide polymorphism in exon 7. Genotype and allele frequencies of eNOS G894T polymorphism among HSP patients and controls are shown in Table 1. The genotype frequencies of the HSP group for GG (wild type), GT (heterozygous) and TT (mutant) genotypes were found as 57 (60\%), 31 (33\%) and seven $(7.4 \%)$, respectively. There were no significant differences between the two groups $(p=0.787$, $p=0.571, \quad p=0.575)$ by the two-proportion $Z$ statistic test. No significant differences were observed between the HSP and control groups when the allele frequencies were compared by
Fisher exact test $(\mathrm{OR}=1.002,95 \% \mathrm{CI}$; range 0.622-1.612) (Table 1).

The patient group was classified according to the clinical complications of HSP. This classification demonstrated that all patients had skin manifestations including palpable purpura, 66 patients (69\%) had joint involvement, 45 patients $(47 \%)$ had gastrointestinal involvement, while 31 patients (33\%) had renal involvement. On the other hand, one group $(n=8)$ was identified for having four manifestations (skin, joint, gastrointestinal, renal). Purpuric rash was present in all patients, so when the patients and controls compared, there was no statistically significant differences in genotype and allele frequencies $(p=0.76 \mathrm{OR}=1.002,95 \% \mathrm{CI}$; range $0.622-1.612$ ). Genotype and allele frequencies of joint involvement $(n=66)$, gastrointestinal involvement $(n=45)$, renal manifestation $(n=31)$ groups and controls $(n=93)$ were compared. There were no significant difference between the groups $(\mathrm{OR}=1.403$ 95\% CI; range 0.849-2.318;

Table 1. Genotype and allele frequencies (\%) of G894T gene polymorphism in the Henoch Schönlein purpura and control groups

\begin{tabular}{|c|c|c|c|c|c|c|c|c|c|c|c|}
\hline \multirow[t]{2}{*}{ Genotype } & \multicolumn{2}{|c|}{ Controls } & \multicolumn{2}{|c|}{ HSP } & \multirow[t]{2}{*}{$p^{*}$} & \multirow[t]{2}{*}{ Allele } & \multicolumn{2}{|c|}{ Controls } & \multicolumn{2}{|c|}{ HSP (total) } & \multirow[t]{2}{*}{$\mathrm{OR}=1.00295 \% \mathrm{CI}$} \\
\hline & $\mathrm{n}$ & $\%$ & $\mathrm{n}$ & $\%$ & & & $\mathrm{n}$ & $\%$ & $\mathrm{n}$ & $\%$ & \\
\hline GG & 54 & 58 & 57 & 60 & 0.787 & G & 142 & 76.3 & 145 & 76.3 & $0.622-1.612$ \\
\hline GT & 34 & 37 & 31 & 33 & 0.571 & $\mathrm{~T}$ & 44 & 23.7 & 45 & 23.7 & \\
\hline TT & 5 & 5.4 & 7 & 7.4 & 0.575 & & & & & & \\
\hline
\end{tabular}




\begin{tabular}{|c|c|c|c|c|c|c|c|c|}
\hline & \multicolumn{2}{|c|}{ Controls ( $\mathrm{n}=93$ ) } & \multicolumn{2}{|c|}{ Joint $(n=66)$} & \multicolumn{2}{|c|}{ GI $(n=45)$} & \multicolumn{2}{|c|}{ Renal $(n=31)$} \\
\hline & $\mathrm{n}$ & $\%$ & $\mathrm{n}$ & $\%$ & $\bar{n}$ & $\%$ & $\mathrm{n}$ & $\%$ \\
\hline \multicolumn{9}{|c|}{ Genotype } \\
\hline GG & 54 & 58 & 33 & 50 & 20 & 44 & 16 & 52 \\
\hline GT & 34 & 37 & 26 & 39 & 19 & 42 & 10 & 32 \\
\hline \multirow[t]{3}{*}{ TT } & 5 & 5.4 & 7 & 11 & 6 & 13 & 5 & 16 \\
\hline & \multicolumn{2}{|c|}{ Controls $(\mathrm{n}=186)$} & \multicolumn{2}{|c|}{ Joint $(n=132)$} & \multicolumn{2}{|c|}{ GI $(n=90)$} & \multicolumn{2}{|c|}{ Renal $(n=62)$} \\
\hline & $\mathrm{n}$ & $\%$ & $\mathrm{n}$ & $\%$ & $\bar{n}$ & $\%$ & $\mathrm{n}$ & $\%$ \\
\hline \multicolumn{9}{|c|}{ Alleles } \\
\hline G & 142 & 76.3 & 92 & 69.7 & 59 & 65.6 & 42 & 67.7 \\
\hline $\mathrm{T}$ & 44 & 23.7 & 40 & 30.3 & 31 & 34.4 & 20 & 32.3 \\
\hline
\end{tabular}

$\mathrm{OR}=1.696 \quad 95 \% \quad \mathrm{CI} ;$ range $0.978-2.941$; $\mathrm{OR}=1.537 \quad 95 \% \quad \mathrm{CI}$; range $0.818-2.888$, respectively (Table 2). Comparison of patients with renal involvement $(n=31)$ with those without renal involvement $(n=64)$ demonstrated that there was no significant difference $(\mathrm{OR}=1.962$ 95\% CI; range 0.985-3.907, $\mathrm{P}_{\mathrm{GG}}=0.249$, $\mathrm{P}_{\mathrm{GT}}=0.957, \mathrm{P}_{\mathrm{TT}}=0.062>0.05$ ).

Glu298Asp polymorphism had a statistically significant effect on all four involvements (skin, joint, gastrointestinal, renal). We matched genotype and allele frequencies between HSP patients with four manifestations and controls. This comparison demonstrated a relationship between the Glu298Asp gene polymorphism and HSP involvement $(\mathrm{OR}=9.682$ 95\% CI; range 2.972-31.541, $\mathrm{P}_{\mathrm{GG}}=0.000$, $\mathrm{P}_{\mathrm{TT}}=0.001<0.05$ ) (Table 3). A relationship was also found when we compared patients with all four involvements with the patient group with other manifestations, except renal involvement $(\mathrm{n}=87) \quad(\mathrm{OR}=12.818 \quad 95 \% \quad \mathrm{CI}$; range 3.886-42.277, $\mathrm{P}_{\mathrm{GG}}=0.000, \mathrm{P}_{\mathrm{TT}}=0.000$ $<0.05)$ (Table 4). In addition, all comparisons were tested the using logistic regression analysis (Table 5). There was no significant relationship in the logistic regression analysis of GG genotype distribution in the patient and control group, odds ratio $(\mathrm{OR})=1.42295 \% \mathrm{CI}$; range 0.823-1.926; $p=0.787)$. Heterozygous genotype for the patient and control group was analyzed using logistic regression and no significantly relation was observed $(\mathrm{OR}=1.146$ 95\% CI; range 0.689-1.724 p=0.571) Data of the TT genotype factor by logistic regression analysis showed no significant differences in the patients and controls $(\mathrm{OR}=1.002$ 95\% CI; range 0.622-1.612). Comparision of joint involvement between patients and controls by logistic regression analysis also showed no significant association for the GG genotype $\mathrm{OR}=1.571 \quad 95 \% \quad \mathrm{CI}$; range 0.945-2.567 $\mathrm{p}=0.314$ and also no significant differences for GT genotype factor OR=1.437 $\mathrm{p}=0.717$. Mutant genotype distribution data showed no significant association $\mathrm{OR}=1.437$ 95\% CI; range 0.849-2.318 $\mathrm{p}=0.240$. The third comparision was between gastrointestinal systems involvement patients and the control group. Wild type genotype data showed no

Table 3. Comparison of genotype and allele frequencies between Henoch Schönlein purpura patients with skin, joint, gastrointestinal, renal involvement, and the controls

\begin{tabular}{|c|c|c|c|c|c|c|c|c|c|c|c|}
\hline \multirow[t]{2}{*}{ Genotype } & \multicolumn{2}{|c|}{ Controls $(n=93)$} & \multicolumn{2}{|c|}{$\mathrm{S}+\mathrm{J}+\mathrm{GI}+\mathrm{R}(\mathrm{n}=8)$} & \multirow[t]{2}{*}{$p^{*}$} & \multirow[t]{2}{*}{ Allel } & \multicolumn{2}{|c|}{ Controls ( $\mathrm{n}=186$ ) } & \multicolumn{2}{|c|}{ HSP (total) $(n=16)$} & \multirow[t]{2}{*}{$\mathrm{OR}=9.68295 \% \mathrm{CI}$} \\
\hline & $\mathrm{n}$ & $\%$ & $\mathrm{n}$ & $\%$ & & & $\mathrm{n}$ & $\%$ & $\mathrm{n}$ & $\%$ & \\
\hline GG & 54 & 58 & 1 & 13 & 0.000 & G & 142 & 76.3 & 4 & 25.0 & \\
\hline GT & 34 & 37 & 2 & 25 & 0.473 & $\mathrm{~T}$ & 44 & 23.7 & 12 & 75.0 & $2.972-31.541$ \\
\hline TT & 5 & 5.4 & 5 & 63 & 0.001 & & & & & & \\
\hline
\end{tabular}

S: Skin; J: Joint; GI: Gastrointestinal; R: Renal involvement; * $\alpha=0.05$; HSP: Henoch Schönlein purpura; CI: Confidence interval; GG: Wild type genotype; GT: Heterozygous genotype; TT: Mutant genotype. 
Table 4. Comparison of genotype and allele frequencies between Henoch Schönlein purpura patients with skin, joint, gastrointestinal, renal involvement and other manifestations

\begin{tabular}{|c|c|c|c|c|c|c|c|c|c|c|c|}
\hline \multirow[t]{2}{*}{ Genotype } & \multicolumn{2}{|c|}{$\mathrm{S}+\mathrm{J}+\mathrm{GI}+\mathrm{R}(\mathrm{n}=8)$} & \multicolumn{2}{|c|}{ Others $(n=87)$} & \multirow[t]{2}{*}{$p^{*}$} & \multirow[t]{2}{*}{ Allel } & \multicolumn{2}{|c|}{$\mathrm{S}+\mathrm{J}+\mathrm{GI}+\mathrm{R}(\mathrm{n}=16)$} & \multicolumn{2}{|c|}{ Others $(n=174)$} & \multirow[t]{2}{*}{$\mathrm{OR}=12.81895 \% \mathrm{Cl}$} \\
\hline & $\mathrm{n}$ & $\%$ & $\mathrm{n}$ & $\%$ & & & $\mathrm{n}$ & $\%$ & $\mathrm{n}$ & $\%$ & \\
\hline GG & 1 & 13 & 56 & 64 & 0.000 & G & 4 & 25 & 141 & 81 & \\
\hline GT & 2 & 25 & 29 & 33 & 0.605 & $\mathrm{~T}$ & 12 & 75 & 33 & 19 & $3.886-42.277$ \\
\hline TT & 5 & 63 & 2 & 3 & 0.000 & & & & & & \\
\hline
\end{tabular}

S: Skin; J: Joint; GI: Gastrointestinal; R: Renal involvement; * $\alpha=0.05$; CI: Confidence interval; GG: Wild type genotype; GT: Heterozygous genotype; TT: Mutant genotype.

significant differences by logistic regression analysis $\mathrm{OR}=1.42195 \% \mathrm{CI}$; range 0.623$1.234 \mathrm{p}=0.130$, GT genotype data showed no significant differences $\mathrm{OR}=1.00195 \% \mathrm{CI}$; range $0.575-1.511 p=0.524$. There was also no significant differences for TT genotype factor $\mathrm{OR}=1.696$ 95\% CI; range 0.978-2.941 $\mathrm{p}=0.154$. The clinical complication of renal involvement demonstrated no effect on the disease alone. Wild type genotype in the renal involvement patient group demonstrated no significant differences $\mathrm{OR}=1.11495 \% \mathrm{CI}$; range $0.612-0.975 ; p=0.532$, for GT genotype factor was no differences significantly by logistic regression $\mathrm{OR}=1.939 \quad 95 \% \quad \mathrm{CI}$; range $0.864-1.342 ; p=0.660$, TT genotype logistic regression analysis have been no differences significantly $\mathrm{OR}=1.537 \quad 95 \% \mathrm{CI}$; range $0.818-2.888 ; p=0.125$.

However, patient with all four involvement significantly had a correlation with high levels of the TT genotype by logistic regression analysis data. Henoch Schönlein purpura patients with purpura, gastrointestinal system, joint, and renal involvement with significant differences for the GG genotype data $\mathrm{OR}=11.824$ 95\% $\mathrm{CI}$; range 4.876-39.941; $\mathrm{p}=0.000$, and also the TT genotype factor showed significant associated by logistic regression $\mathrm{OR}=9.682$ 95\% CI; range 2.972-31.541 $\mathrm{p}=0.001$, but there was no significant differences for GT genotype OR=1.712 95\% CI; range 0.9341.612; $p=0.473$. In addition, comparison of this logistic regression analysis for the patient

\begin{tabular}{|c|c|c|c|}
\hline Group & Genotype & $p$ & Odds ratio $95 \% \mathrm{CI}$ \\
\hline Total HSP-controls & GG & 0.787 & $1.422(0.823-1.926)$ \\
\hline Purpura involvement-controls & $\begin{array}{l}\text { GT } \\
\text { TT }\end{array}$ & $\begin{array}{l}0.571 \\
0.575\end{array}$ & $\begin{array}{c}1.146(0.689-1.724) \\
1.002(0.622-1.612)\end{array}$ \\
\hline Joint involvement patients-controls & $\begin{array}{l}\text { GG } \\
\text { GT } \\
\text { TT }\end{array}$ & $\begin{array}{l}0.314 \\
0.717 \\
0.240\end{array}$ & $\begin{array}{l}1.571(0.945-2.567) \\
1.437(0.892-1.998) \\
1.403(0.849-2.318)\end{array}$ \\
\hline GIS involvement patients-controls & $\begin{array}{l}\text { GG } \\
\text { GT } \\
\text { TT }\end{array}$ & $\begin{array}{l}0.130 \\
0.524 \\
0.154\end{array}$ & $\begin{array}{l}1.421(0.623-1.234) \\
1.001(0.575-1.511) \\
1.696(0.978-2.941)\end{array}$ \\
\hline Renal involvement-controls & $\begin{array}{l}\text { GG } \\
\text { GT } \\
\text { TT }\end{array}$ & $\begin{array}{l}0.532 \\
0.660 \\
0.125\end{array}$ & $\begin{array}{l}1.114(0.612-0.975) \\
1.939(0.864-1.342) \\
1.537(0.818-2.888)\end{array}$ \\
\hline $\begin{array}{l}\text { Purpura }+ \text { joint }+ \text { GIS + renal involvement } \\
\text { patients with controls }\end{array}$ & $\begin{array}{l}\text { GG } \\
\text { GT } \\
\text { TT }\end{array}$ & $\begin{array}{l}0.000 \\
0.473 \\
0.001\end{array}$ & $\begin{array}{c}8.423(2.234-28.459) \\
1.712(0.934-1.612) \\
9.682(2.972-31.541)\end{array}$ \\
\hline $\begin{array}{l}\text { Purpura }+ \text { joint }+ \text { GIS + renal involvement } \\
\text { with other patients }\end{array}$ & $\begin{array}{l}\text { GG } \\
\text { GT } \\
\text { TT }\end{array}$ & $\begin{array}{l}0.000 \\
0.605 \\
0.000\end{array}$ & $\begin{array}{c}11.824(4.876-39.941) \\
1.234(0.376-0.982) \\
12.818(3.886-42.277)\end{array}$ \\
\hline
\end{tabular}


group with all four involvements was made lastly. Furthermore, this group data showed significant differences for TT and GG genotype but there was no significant differences for heterozygous patients. Mutant genotype data was $\mathrm{OR}=12.818$ 95\% CI; range 3.886-42.277; $\mathrm{p}=0.000$, GT genotype data was $\mathrm{OR}=1.23495 \%$ $\mathrm{CI}$; range 0.376-0.982 $\mathrm{p}=0.605$, GG genotype was $\mathrm{OR}=11.82495 \% \mathrm{CI}$; range 4,876-39,941; $\mathrm{p}=0.000$.

\section{DISCUSSION}

Although the primary cause of HSP is unclear, many researchers believe that infection-related immunological processes including upper respiratory tract infections particularly, are more responsible than damage of the immune system. ${ }^{21}$ Recent studies have reported that many different genes have an important role for the HSP phenotype. It has been reported that HLA A2, $\mathrm{A} 11$, and B35 antigens showed an increased risk for a predisposition to HSP and HSP patients with nephrotic proteinuria had higher HLA-DRB1*13 positivity. ${ }^{22,23}$ Results of Amoli et al. ${ }^{24}$ supported the role of HLA B35 in the susceptibility for HSP patient with nephritis. In another study, transforming growth factor-beta (TGF- $\beta$ ) gene C509T polymorphism was associated with HSP. The mutant genotype (-509 TT) was found to be more common in HSP patients than controls. ${ }^{25}$ Therefore, it is not interesting that most of these studies were associated with immunogenetics of vasculitis which occurred as a result of the accumulation of immune complexes. ${ }^{26}$

Bruce et al. ${ }^{27}$ reported that $\mathrm{NO}$ was produced in excessive amounts in systemic vasculitis. In many studies, the Glu298Asp genotype and allele frequencies were found to be much higher in Behçet's disease, which is an immune mediated systemic vasculitis. ${ }^{28-31}$ Likewise Heeringa et al. $^{32}$ reported that decreased NO production by endothelial cells, in conjunction with increased NO production by inducible nitric oxide synthase-positive inflammatory cells causes renal tissue damage in Wegener's granulomatosis, which is a systemic vasculitis affecting small and medium-sized vessels. In addition, unclear etiopathogenesis of large vessel vasculitis including Takayasu arteritis and giant cell arteritis may be associated with inducible NOS gene polymorphism. ${ }^{33}$ Based on these studies, NO may play a role in the mechanism of vasculitis or may have an impact on the clinical progression of vasculitis. However, there are only a few studies about an association between NOS gene and HSP. One of these associations is NOS2A promoter polymorphism, which may play a role in the susceptibility to HSP and the development of nephritis. ${ }^{34}$ In an another study from Northwest Spain, a variable number tandem repeat polymorphism in intron 4 , a T/C polymorphism at position -786 in the promoter region, and a polymorphism in exon 7 (298Glu/Asp or $5557 \mathrm{G} / \mathrm{T}$ ) of the eNOS gene were studied in a limited number of HSP patients. According to this study, any significant differences have been found in the allele or genotype frequencies for eNOS polymorphisms between HSP patients for the presence of nephritis, or joint and also gastrointestinal manifestations and controls. ${ }^{35}$ However, eNOS haplotype association was observed in patients with biopsy-proven giant cell vasculitis, a large blood vessel vasculitis involving mainly elderly people, when compared with matched controls. ${ }^{36}$

Association between Glu298Asp gene polymorphism and many renal sequales including end-stage renal disease, ${ }^{37-38}$ glomerulonephritis, ${ }^{39}$ diabetic nephropaty, ${ }^{40}$ and immunoglobulin A nephropaty ${ }^{41}$ have been reported. Serrano et al. ${ }^{42}$ suggested that eNOS deficiency may affect the severity of gastrointestinal complications. With reference to studies showing the importance of eNOS gene in the gastrointestinal system, joint and renal diseases, we classified HSP patients according to the clinical symptoms of the disease. We the compared each HSP group separately with the controls. We did not find any differences, except for HSP patients with all sequelaes as skin, joint, gastrointestinal and renal involvements. However we observed an interesting result comparing the patient group having all involvement, and patients with renal manifestations alone $(p<0.005)$, and with the controls $(p<0.005)$. These comparisions showed statistically significant differences. Mutant allel and genotype frequences increased in HSPs with statistically four sequales.

In conclusion, our data showed that HSP does not have an association with eNOS Glu298Asp 
polymorphism. Nonetheless, we conclude that further comprehensive studies in other regions of the eNOS gene may be more useful for revealing the genetic predisposition of this primary cutaneous vasculitis. Therefore, further largescale studies are required to shed light on the potential role of eNOS polymorphisms in HSP.

\section{Declaration of conflicting interests}

The authors declared no conflicts of interest with respect to the authorship and/or publication of this article.

\section{Funding}

This research was supported by Grant 08202018 from University of Necmettin Erbakan, Scientific Research Projects Department (BAP), Konya, Turkey.

\section{REFERENCES}

1. Casanueva B, Rodriguez-Valverde V, Merino J, Arias M, Garcia-Fuentes M. Increased IgA-producing cells in the blood of patients with active Henoch-Schönlein purpura. Arthritis Rheum 1983;26:854-60.

2. Tizard EJ, Hamilton-Ayres MJ. Henoch Schonlein purpura. Arch Dis Child Educ Pract Ed 2008;93:1-8.

3. Ballinger S. Henoch-Schonlein purpura. Curr Opin Rheumatol 2003;15:591-4.

4. Saulsbury FT. Henoch-Schönlein purpura. Curr Opin Rheumatol 2010;22:598-602.

5. García-Porrúa C, Calviño MC, Llorca J, Couselo JM, González-Gay MA. Henoch-Schönlein purpura in children and adults: clinical differences in a defined population. Semin Arthritis Rheum 2002;32:149-56.

6. Amoli MM, Mattey DL, Calviño MC, Garcia-Porrua C, Thomson W, Hajeer AH, et al. Polymorphism at codon 469 of the intercellular adhesion molecule-1 locus is associated with protection against severe gastrointestinal complications in Henoch-Schönlein purpura. J Rheumatol 2001;28:1014-8.

7. Amoli MM, Thomson $\mathrm{W}$, Hajeer AH, Calviño MC, Garcia-Porrua C, Ollier WE, et al. Interleukin 8 gene polymorphism is associated with increased risk of nephritis in cutaneous vasculitis. $J$ Rheumatol 2002;29:2367-70.

8. Amoli MM, Calviño MC, Garcia-Porrua C, Llorca J, Ollier WE, Gonzalez-Gay MA. Interleukin 1beta gene polymorphism association with severe renal manifestations and renal sequelae in Henoch-Schönlein purpura. J Rheumatol 2004;31:295-8.

9. Rueda B, Perez-Armengol C, Lopez-Lopez S, GarciaPorrua C, Martín J, Gonzalez-Gay MA. Association between functional haplotypes of vascular endothelial growth factor and renal complications in HenochSchönlein purpura. J Rheumatol 2006;33:69-73.
10. Amoli MM, Thomson W, Hajeer AH, Calviño MC, Garcia-Porrua C, Ollier WE, et al. HLA-DRB1*01 association with Henoch-Schönlein purpura in patients from northwest Spain. J Rheumatol 2001;28:1266-70.

11. Torres O, Palomino-Morales R, Miranda-Filloy JA, Vazquez-Rodriguez TR, Martin J, Gonzalez-Gay MA. IL-18 gene polymorphisms in Henoch-Schönlein purpura. Clin Exp Rheumatol 2010;28:114.

12. Shankarishan P, Borah PK, Ahmed G, Mahanta J. Prevalence of endothelial nitric oxide synthase (eNOS) gene exon 7 Glu298Asp variant in North Eastern India. Indian J Med Res 2011;133:487-91.

13. McDonald DM, Alp NJ, Channon KM. Functional comparison of the endothelial nitric oxide synthase Glu298Asp polymorphic variants in human endothelial cells. Pharmacogenetics 2004;14:831-9.

14. Wang XL, Wang J. Endothelial nitric oxide synthase gene sequence variations and vascular disease. Mol Genet Metab 2000;70:241-51.

15. Katusic ZS, Caplice NM, Nath KA. Nitric oxide synthase gene transfer as a tool to study biology of endothelial cells. Arterioscler Thromb Vasc Biol 2003;23:1990-4.

16. Freedman JE. Oxidative stress and platelets. Arterioscler Thromb Vasc Biol 2008;28:11-6.

17. Cherney DZ, Scholey JW, Zhou J, ZimpelmannJ, Kennedy $\mathrm{C}$, Burns $\mathrm{KD}$, et al. Endothelial nitric oxide synthase gene polymorphisms and the renal hemodynamic response to L-arginine. Kidney Int 2009;75:327-32.

18. Mulligan MS, Moncada S, Ward PA. Protective effects of inhibitors of nitric oxide synthase in immune complexinduced vasculitis. Br J Pharmacol 1992;107:1159-62.

19. Marsden PA, Heng HH, Scherer SW, Stewart RJ, Hall AV, Shi XM, et al. Structure and chromosomal localization of the human constitutive endothelial nitric oxide synthase gene. J Biol Chem 1993;268:17478-88.

20. Mills JA, Michel BA, Bloch DA, Calabrese LH, Hunder GG, Arend WP, et al. The American College of Rheumatology 1990 criteria for the classification of Henoch-Schönlein purpura. Arthritis Rheum 1990;33:1114-21.

21. Roberts PF, Waller TA, Brinker TM, Riffe IZ, Sayre JW, Bratton RL. Henoch-Schönlein purpura: a review article. South Med J 2007;100:821-4.

22. Peru H, Soylemezoglu O, Gonen S, Cetinyurek A, Bakkaloğlu SA, Buyan N, et al. HLA class 1 associations in Henoch Schonlein purpura: increased and decreased frequencies. Clin Rheumatol 2008;27:5-10.

23. Soylemezoglu O, Peru H, Gonen S, Cetinyurek A, Ozkaya O, Bakkaloğlu S, et al. CTLA-4 +49 A/G genotype and HLA-DRB1 polymorphisms in Turkish patients with Henoch-Schönlein purpura. Pediatr Nephrol 2008;23:1239-44.

24. Amoli MM, Thomson W, Hajeer AH, Calviño MC, Garcia-Porrua C, Ollier WE, et al. HLA-B35 association with nephritis in Henoch-Schönlein purpura. J Rheumatol 2002;29:948-9. 
25. Yang YH, Lai HJ, Kao CK, Lin YT, Chiang BL. The association between transforming growth factor-beta gene promoter C-509T polymorphism and Chinese children with Henoch-Schönlein purpura. Pediatr Nephrol 2004;19:972-5.

26. Fietta P. Systemic vasculitides: immunogenetics and familial clustering. Clin Exp Rheumatol 2004;22:238-51.

27. Bruce IN, Harris CM, Nugent A, McDermott BJ, Johnston GD, Bell AL. Enhanced endotheliumdependent vasodilator responses in patients with systemic vasculitis. Scand $J$ Rheumatol 1997;26:318-24.

28. Şahan F, Ozdemir Ş, Karakuzu A, Aktas A, Kızıltunc A. The levels of nitric oxide in Behçet's disease. T Klin Dermatoloji 2001;11:77-80.

29. Kim JU, Chang HK, Lee SS, Kim JW, Kim KT, Lee SW, et al. Endothelial nitric oxide synthase gene polymorphisms in Behçet's disease and rheumatic diseases with vasculitis. Ann Rheum Dis 2003;62:1083-7.

30. Oksel F, Keser G, Ozmen M, Aksu K, Kitapcioglu $\mathrm{G}$, Berdeli A, et al. Endothelial nitric oxide synthase gene Glu298Asp polymorphism is associated with Behçet's disease. Clin Exp Rheumatol 2006;24:S79-82.

31. Ben Dhifallah I, Houman H, Khanfir M, Hamzaoui K. Endothelial nitric oxide synthase gene polymorphism is associated with Behçet's disease in Tunisian population. Hum Immunol 2008;69:661-5.

32. Heeringa P, Bijl M, de Jager-Krikken A, Zandvoort A, Dijkstra G, Moshage $\mathrm{H}$, et al. Renal expression of endothelial and inducible nitric oxide synthase, and formation of peroxynitrite-modified proteins and reactive oxygen species in Wegener's granulomatosis. J Pathol 2001;193:224-32.

33. Seko Y. Giant cell and Takayasu arteritis. Curr Opin Rheumatol 2007;19:39-43.

34. Martin J, Paco L, Ruiz MP, Lopez-Nevot MA, GarciaPorrua $\mathrm{C}$, Amoli $\mathrm{MM}$, et al. Inducible nitric oxide synthase polymorphism is associated with susceptibility to Henoch-Schönlein purpura in northwestern Spain. Rheumatol 2005;32:1081-5.

35. Amoli MM, Garcia-Porrua C, Calviño MC, Ollier WE, Gonzalez-Gay MA. Lack of association between endothelial nitric oxide synthase polymorphisms and Henoch-Schönlein purpura. J Rheumatol 2004;31:299-301.

36. Amoli MM, Garcia-Porrua C, Llorca J, Ollier WE, Gonzalez-Gay MA. Endothelial nitric oxide synthase haplotype associations in biopsy-proven giant cell arteritis. J Rheumatol 2003;30:2019-22.

37. Yokoyama K, Tsukada T, Matsuoka H, Hara S, Yamada A, Kawaguchi Y. High accumulation of endothelial nitric oxide synthase (ecNOS): a gene polymorphism in patients with end-stage renal disease. Nephron 1998;79:360-1.

38. Wang Y, Kikuchi S, Suzuki H, Nagase S, Koyama A. Endothelial nitric oxide synthase gene polymorphism in intron 4 affects the progression of renal failure in non-diabetic renal diseases. Nephrol Dial Transplant 1999;14:2898-902.

39. Burg M, Menne J, Ostendorf T, Kliem V, Floege J. Genepolymorphisms of angiotensin converting enzyme and endothelial nitric oxide synthase in patients with primary glomerulonephritis. Clin Nephrol 1997;48:205-11.

40. Fujita H, Narita T, Meguro H, Ishii T, Hanyu O, Suzuki $\mathrm{K}$, et al. Lack of association between an ecNOS gene polymorphism and diabetic nephropathy in type 2 diabetic patients with proliferative diabetic retinopathy. Horm Metab Res 2000;32:80-3.

41. Morita T, Ito $H$, Suehiro T, Tahara K, Matsumori A, Chikazawa $\mathrm{H}$, et al. Effect of a polymorphism of endothelial nitric oxide synthase gene in Japanese patients with IgA nephropathy. Clin Nephrol 1999;52:203-9.

42. Serrano NC, Páez C, Correa PA, Anaya JM. Endothelial nitric oxide synthase gene polymorphism is associated with systemic lupus erythematosus. J Rheumatol 2004;31:2163-8. 